\title{
'n Nuwe ekumeniese geloofsbelydenis?
}

\section{BJ Engelbrecht}

\section{Abstract \\ A new ecumenical confession of faith}

Recently theologians, church leaders and even churches from all over the world expressed the desirability of a new confession of faith, preferably an ecumenical confession. The Reformed Church in America proposed a new confession with their Song of Hope. They still maintain large parts of their 16th century reformed confessions but the following motives played a role in their desire for a new confession:

- The necessity to correct the existing, 'old' confessions in the light of modern scientific Bible-research, $\mathrm{e} g$ on the doctrine of predestination.

- The need for additional confession-pronouncements on modern-day issues and experiences, unknown to the church in the 16th century.

- The desirability of a new form (language) to communicate with modern man.

- The sensitivity of the churches of today towards church-unity and the trends living in the oikoumén $\bar{e}$, e $\mathrm{g}$ their social awareness.

We then proceed to treat the motives why a reformed Church überhaupt needs and forms a confession. In the light of these motives the question arises whether our Church really needs a new confession today; is the exposition of the existing confessions in theology, catechesis, preaching and modem church-hymns not enough to translate and communicate the existing confessions to modern man and to address modern-day issues?

\section{DIE WENSLIKHEID EN UITVOERBAARHEID VAN 'N NUWE EKUMENIESE GELOOFSBELYDENIS}

Een van die wesenlike elemente in die kerkbeskouing van die kerkhervormers is uitgedruk in die spreuk: ecclesia reformata semper reformanda, wat beteken 'n Hervormde Kerk moet gedurigdeur hervorm word'. Die saak sit naamlik só inmekaar, dat die Skrif alleen die maatstaf van die leer en lewe van die kerke van die Kerkhervorming is. Daarom is die Protestantse kerke gedurigdeur besig met die studie van die Skrif en daarom moet die vraag gedurigdeur gestel word of die hedendaagse lewenspraktyk èn die hedendaagse belydenis en leer van die kerk nog 
ooreenstem met die maatstaf van die Skrif, veral namate nuwe gegewens en metodes van Skrifstudie nuwe Skriftuurlike insigte en perspektiewe ontdek.

\subsection{Resente voorbeelde}

Dit lê daarom in die wese van die Protestantse kerke dat die vraag gevra word na die nodigheid van 'n nuwe belydenis wat helder sal klink in die omstandighede en taal van vandag. Ons noem slegs 'n paar resente voorbeelde.

Veral ná die Tweede Wêreldoorlog het daar in die Nederlandse Hervormde Kerk stemme opgeklink wat die vraag na 'een nieuw belijden' gestel het. Daar is in hierdie diskussie heengewys na die geweldige kerklike oplewing in Nederland èn na die voorbeeld wat die Sinode van die Belydende Kerk in Barmen in Duitsland in 1934 gestel het, toe hulle teenoor die Nazisme en die liberale neigings van die Geloofsbeweging van Duitse Christene (wat baie simpatiek teenoor die Nazisme was) hulle Deklarasie (wat in feite 'n kerklike belydenis was) opgestel en wêreldkundig gemaak het. Ander geleerdes het daarop gewys dat die Barmense Deklarasie eintlik nie 'n nuwe belydenis was nie, maar dat dit opnuut Calvyn belydend herhaal het, naamlik dat die fondament van die kerk die openbaring van God in Jesus Christus is en nie sogenaamde openbarings in die natuur en in die geskiedenis nie, en dat die primêre taak van die kerk die prediking van die evangelie van die vrye genade van God is.

Wanneer prof $\mathrm{dr} \mathrm{H}$ van der Linde opnuut die vraag na 'n nuwe belydenis stel, na 'n ekumeniese belydenis, dan loop hy nie net in die voetspore van ' $n$ resente Nederlandse en Duitse tradisie nie, maar dan reken hy ook met die situasie van die kerk van vandag, naamlik met die ekumeniese strewe van kerke oor die hele wêreld. Hy sê oor die werk aan so 'n nuwe ekumeniese belydenis:

We doen dat als oecumenische christenen, nog komend en nog levend uit verschillende deeltradities. Hoe meer we samen het antwoord zoeken op de vragen die samenklonteren rond de vraag naar de oikouméne, Gods Wereldhuis Van de Toekomst, met alle dimensies en perspectiven vandien; hoe meer we ook inhoudelijk elkaar zullen vinden, met eenwording daaruit volgend. Eenheid zal de toegift zijn op dit eendrachtig conciliair bezigzijn (kyk Die Hervormer Julie 1981, bl 6 en Cullmann 1959). 
'n Verdere voorbeeld wat ons uit die resente tyd wil noem, is die daadwerklike poging tot 'n nuwe belydenis van die Reformed Church in America. Dit wil doelbewus aansluit by die drie Calvinistiese belydenisskrifte van die verlede, naamlik die Nederlandse Geloofsbelydenis, die Heidelbergse Kategismus en die Dordtse Leerreëls. Tog wil dit Skriftuurlik byderwets wees èn aansluit by die kerklike situasie van vandag. Dit heet Our song of hope. Hulle het dit offisieel aanvaar as 'A provisional confession of faith of the Reformed Church in America' op hulle Sinodesitting van 1974. Die gepubliseerde 'belydenis' beslaan een-en-twintig stansas (koeplette) van ongeveer agt versreëls elk, dit wil sê ongeveer ses gedrukte bladsye. Hulle het dit in 1975 wêreldwyd aan kerke vir kommentaar uitgestuur. Sekere dele daarvan is ook van musiek voorsien, selfs vir kitaarbegeleiding. Laasgenoemde is natuurlik daar om aansluiting by die jongmense van vandag te probeer vind. Uit die begeleidende skrywes en die 'Commentary and Appendixes' van dr EP Heideman wat die teks van hierdie 'belydenis' vergesel, blyk die volgende drie motiewe waarom die betrokke Kerk opnuut (èn met 'n nuwe belydenis) sy geloof onder woorde wil bring:

- Beide wat die vorm en die inhoud betref, wil hulle in 'die taal van vandag', en nie in verslete of onverstaanbare woorde en begrippe van lank gelede nie, hulle geloof bely.

- Tweedens wil hulle rekening hou met die veranderde 'kerklike situasie', wat in feite beteken dat die ekumeniese beweging, gevoel en denke sterk mee moet spreek in 'n hedendaagse geloofsbelydenis.

- Miskien is die belangrikste rede vir 'n nuwe geloofsbelydenis die volgende: Die Reformed Church in America het die Skrif noukeurig bestudeer en in die lig daarvan na die belydenisskrifte van hulle kerklike tradisie gekyk. 'n Hele aantal kardinale belydeniswaarhede het die toets van die Skrif deurstaan. Ons noem slegs die volgende: Die soewereiniteit van God; die trinitariese belydenisse van die $\mathrm{Ou}$ Kerk; die Christologie van die Ou Kerk; die Pneumatologie van die Ou Kerk; die leerstuk van die regverdigmaking deur die geloof alleen; die leerstukke van die verbond en die kerk; die gesag van die Skrif en die Calvinistiese leer oor die sakramente; die beklemtoning van die hemelvaart van Christus, sy wederkoms en die laaste oordeel. Maar hulle meen dat hulle in die lig van hulle Skrifstudie oor drie leerstellings van die Calvinistiese kerkhervorming moet verskil: Van die Nederlandse Geloofsbelydenis verskil hulle belydenis van artikel 36 wat handel oor die burgerlike owerheid (= die Staat); van die Heidelbergse Kategismus verskil hulle oor die begrip 'geregtig- 
heid'. Die Kategismus sien, volgens hulle, 'geregtigheid' te veel in terme van die herstel van die gebroke verhouding met God. In die lig van die ekumeniese denke, glo die Reformed Church in America dat ons wel meer klem moet lê (soos hulle dit sien) op die sosiale geregtigheid, die horisontale geregtigheid tussen mens en medemens; op die geregtigheid wat ons moet doen en nie soseer op die geregtigheid wat ons van God ontvang nie. Ja, ook die hoop (soos blyk uit die titel 'Our song of hope') het 'n sterk horisontale, 'n sterk sosiaal-politieke dimensie. Op gelyke wyse slaan versoening baie beslis op inter-menslike, inter-raslike, inter-volkige versoening. Van die Leerreëls van Dordt verskil hulle (op grond van deeglike Skrifstudie, soos hulle meen) oor die leerstuk aangaande die 'ewige uitverkiesing'. Hulle glo dat daar veel meer klem gelê moet word op die menslike verantwoordelikheid. Verder: Wanneer ons aan God die verskuldigde eer vir ons verlossing gee, dan is dit nie nodig om dit te doen in die spekulatiewe terme van ewige raadsbesluite nie.

Hier het ons dan 'n belydenis wat, wat sy vorm betref, heeltemal nuut is en wat sy inhoud betref, aansluit by die belydenisskrifte van die verlede en tog op baie belangrike punte nuut is, beide in die sin van antitese en van aanvulling. Die volgende faktore het daarin 'n rol gespeel: die manier waarop die moderne mens dink en praat; die ekumeniese situasie en denke (soos die sosiale motief in die ekumeniese denke); die resultate van nuwe Skrifstudie.

\subsection{Motiewe agter 'n geloofsbelydenis}

Voordat ons egter die vraag beantwoord of ' $n$ nuwe belydenis vandag nodig is en of ' $n$ ekumeniese belydenis werklik ' $n$ uitvoerbare moontlikheid is, moet ons eers sekere vrae beantwoord, soos: Wat het die kerk daartoe gebring het om geloofsbelydenisse op te stel? Wat is die kriteria waaraan ' $n$ kerklike geloofsbelydenis moet voldoen? ensovoorts.

As antwoord op die eerste vraag wil ons stel dat ' $n$ hele aantal faktore daarvoor verantwoordelik was dat die kerk deur die eeue geloofsbelydenisse opgestel het; dat dit eintlik in die wese van die Christelike kerk lê om sy geloof te bely en sy belydenis, ter wille van die vastheid, duursaamheid en eenvormigheid, op skrif te stel. Laat ons in dié verband na 'n paar faktore kyk:

\subsubsection{Die geloofsbelydenis as simbool}

Die Latynse wood vir geloofsbelydenis is symbolum (Grieks = súmbolos), dit wil sê die vaandel, die vlag waaronder 'n bepaalde eenheid 
soldate geveg het. Aanvanklik het elke groep vegters wat bymekaar gehoort het (net soos ons sportspanne vandag) 'n vaandel van 'n bepaalde kleur (sê maar: wit, swart, groen, rooi, geel, ens) gehad wat ook op hulle helms en hulle klere voorgekom het en waaraan hulle uitgeken kon word. Die rede daarvoor was dat hulle op so 'n wyse daaraan uitgeken kon word, sodat 'n soldaat in die hitte van die geveg nie naderhand met sy eie mense of bondgenote handgemeen sou raak nie. Die 'simbool', die vaandel, die vlag het in hierdie verband die volgende funksies gehad: dit het 'n bepaalde groep afgesonder, daaraan 'n bepaalde identiteit gegee en tegelykertyd 'n gevoel van onderlinge verbondenheid en inspirasie tot die stryd laat ontstaan. Op dieselfde wyse het die geloofsbelydenis as vaandel daartoe gedien om die Christene van die heidene en Jode af te sonder, aan hulle 'n eie identiteit te gee, hulle onderling saam te bind en te inspireer om vir hierdie belydenis te stry en ook te ly as dit moet. Hierdie belydenis was partymaal baie kort soos byvoorbeeld: 'Jesus is die Here' (vgl Rom 10: 9 en 1 Kor 12: 3). Hierdie kort belydenis is gestel teenoor die heidene wat dikwels die keiser godsdienstig vereer het en gesê het: 'Die keiser is Here!' Die Twaalf Artikels aan die ander kant, is ' $n$ veel omvattender belydenis as bogenoemde, terwyl die Nederlandse Geloofsbelydenis sewe-en-dertig artikels het, en gemiddeld vyf-en-twintig gedrukte bladsye beslaan. Juis hierdie laasgenoemde belydenis wat in 1561 deur Guido de Brès opgestel is, is onder andere 'n goeie voorbeeld van 'n belydenis as 'simbool', as vlag en vaandel. Die Rooms-Katolieke, wat ook die staatsmag in hulle hande gehad het, het die egte Hervormdes met die destyds-staatsvyandige en -staatsgevaarlike Wederdopers verwar en hulle vervolg. Om die egte Hervormdes egter af te sonder van die Wederdopers (èn van die Rooms-Katolieke), om hulle duidelik te identifiseer, tot 'n eenheid saam te bind en om dié waarheid waaraan hulle glo en waarvoor hulle bereid is om te stry en te ly, duidelik te stel, het De Brès hierdie belydenis opgestel (kyk o a Koopmans 1949: 7-14).

Die hoofwoorde vir die belydenis as vaandel is dus: afsondering, eie identiteit, onderlinge verbondenheid en inspirasie deur die waarheid.

\subsubsection{Die geloofsbelydenis as die hoofpunte van die Bybelse leerinhoud}

'n Tweede faktor wat die opstel van 'n belydenis deur die kerk noodsaaklik maak, is die behoefte van die kerk om 'n redelike kort, oorsigtelike samevatting van die hoofpunte van die leerinhoud van die Bybel te hê om dit telkens opnuut onder die aandag van die lidmate te 
bring, maar veral om dit aan die opgroeiende kinders en aan hulle onder wie die kerk sendingwerk doen, te leer. Dit staan bekend as die kategetiese en missiologiese motief agter belydenisvorming. Toe die Ou Kerk sendingwerk onder die heidene gedoen het, het die kerk behoefte gehad aan ' $n$ kort samevatting van haar Bybelse geloof sodat hulle wat tot bekering gekom het, dit kon bely en gedoop kon word. Op hierdie wyse het uiteindelik die Twaalf Artikels en die Geloofsbelydenis van Nicea rondom die trinitariese geloofsbelydenisse met die oog op die doop ontstaan. Om hulle makliker te onthou en dieper te laat insink in die lewe van die belyer, is hulle dikwels gesing (kyk Van Selms 1952: 10, 15, 21, 158). Om die kinders in ons kerk (wat alreeds gedoop is) voor te berei om hulle geloof te bely en dan tot die heilige Nagmaal toe te laat (die Nagmaal wat by uitnemendheid die sakrament van die 'gemeenskap van die heiliges' is), is die Heidelbergse Kategismus as belydenis van die kerk opgestel.

Daarom sê keurvors Frederik III van die Palts (onder wie se leiding die Heidelberger opgestel is) dan ook in 1563 dat dit dringend noodsaaklik was 'om ' $n$ kort en eenvoudige samevatting van die hoofpunte van die suiwer Christelike leer wat uit die Bybel geput is', te maak om die lidmate daaruit op te voed 'in die regte kennis en vrees van die Almagtige en van sy saligmakende Woord as die enigste fondament van alle deugde en gehoorsaamheid'. Die Kategismus moet dien as "n eendragtige onderwysing uit 'n eenstemmige Kategismus' om 'allerlei verkeerdhede, misverstand en onordelikheid' te bekamp en om die regte kennis en vrees vir 'die Almagtige en sy Woord' by te bring (kyk Bakhuizen van den Brink 1940: 144-147) en Oberholzer 1986: 16-21).

Wie noukeurig na Keurvors Frederik luister, sal nie alleen opmerk dat die Kategismus as kerklike belydenis met die oog op kategese opgestel is nie, maar ook dat die regte leer en die regte lewe onlosmaaklik met mekaar saamhang, dat die regte lewe as ' $t$ ware vanself uit die regte geloof voortspruit. Ons kan ook sê dat Etiek (die leer van die regte lewe) as 't ware vanself uit die Dogmatiek (die wetenskap van die regte leer en belydenis) voortvloei.

Maar voordat ons 'n ander motief vir kerklike belydenisvorming noem, moet ons nog twee opmerkings in verband met die huidige onderwerp maak:

- Wanneer 'n belydenis as Kategismus opgestel word, as 'n samevatting van die hoofpunte van die Bybel, dan beteken dit nie dat ons nou naas die Bybel ' $n$ menslike geskrif stel nie. Die Bybel is in homself genoegsaam en duidelik, maar ons as skepsels en sondaars 
se verstand is beperk. Die Kategismus sê dus nie iets anders as die Bybel nie, maar sê dit anders as die Bybel: korter, oorsigteliker en meer sistematies (ter wille van ons bevatlikheid) as die Bybel. Hierdie feit lê 'n ontsettende verantwoordelikheid op die opstellers van 'n kerklike kategismus. Dit mag nie iets sê wat nie in die Bybel self staan nie en dit mag nie iets weglaat wat die Bybel self as ' $n$ hoofpunt beskou nie. ' $n$ Kategismus moet dus die leser terugvoer na die Bybel van waaruit dit geneem is.

- Dit het geblyk dat 'n belydenisskrif, ook in die vorm van 'n kategismus, die hoofpunte van die leer van die Bybel sistematies saamvat. Maar in die Bybel vind 'n mens heel selde blote leer; meestal is die leer van die Bybel ten nouste met die heilsgeskiedenis verweef. Daarom sal die studie van 'n kategismus altyd aangevul en begelei moet word deur die studie van Bybelse heilsgeskiedenis.

\subsubsection{Die geloofsbelydenis as die stryd teen dwaalleer}

'n Derde faktor wat die kerk tot belydenisvorming dwing, is die kerk se stryd teen dwaalleer. Dit word die polemiese motief in die proses van belydenisvorming genoem. Agter die skynbaar skraal woorde waarmee die Twaalf Artikels èn die Belydenisse van Nicea en Athanasius oor Christus en die heilige Drie-eenheid praat, lê daar letterlik die stryd van die kerk vir etlike eeue om lewe en dood teen die dwaalleer. As die dwaalleer die oorhand oor die Bybelse waarheid sou kry, was dit werklik die einde van die Christendom. In Matteus 18: 7 sê Jesus dat 'dit noodsaaklik is dat daar struikelblokke kom' (A B V 1933), heel waarskynlik omdat die geloof daardeur op die proef gestel en sodoende gelouter word. 'n Mens kan dieselfde van die dwaalleer sê. Die positiewe sy daarvan is dat dit die kerk deur gedurige konfrontasie en die soek na uitspringmoontlikhede dwing om die Bybelse waarheid met groot noukeurigheid te formuleer. Wanneer 'n mens teen 'n gedugte vyand stry, moet jy sorg dat jou eie instelling, wapens en metodes so volmaak as moontlik is.

'n Mens kan met groot stelligheid sê dat die meerderheid van belydenisuitsprake uiters noukeurige formulerings teenoor twispunte in die leer, teenoor ' $n$ dwaalleer of dwaalleringe is. Om die Bybelse waarheid dat Jesus Christus (hoewel $\mathrm{Hy}$ 'n afsonderlike goddelike persoon is), een in wese met die Vader is, tot uitdrukking te bring, sê die Geloofsbelydenis van Nicea byvoorbeeld van die Here Jesus Christus: 'Hy is God uit God, lig uit lig, waaragtige God uit waaragtige God.' In ' $n$ sekere sin is hierdie drie belydenisuitsprake oor Jesus Christus ' $n$ 
herhaling van mekaar, maar hierdie herhaling was uiters noodsaaklik. Toe die belydenis wou sê dat Jesus Christus wesenlik God is, het hulle op grond van die Bybel gesê: 'God uit God'. Die dwaalleer dat Jesus Christus na sy Godheid ondergeskik aan die Vader was, was hiermee tydelik afgesny. Maar toe het die vindingryke dwaalleraars 'n uitspringgeleentheid gevind deur te sê: 'Goed, Hy is God uit God, maar dan 'n mindere God uit 'n meerdere God.' Om hierdie onbybelse dwaalleer verder te bekamp, het die Kerk van Jesus Christus bely: ' $\mathrm{Hy}$ is lig uit lig.' Dit het beteken dat die Vader die Ligbron is en die Seun die Ligstraal. Hulle is dus albei van dieselfde wese en net soos ' $n$ ligbron sonder ligstraal geen ligbron is nie, en daar ook geen ligstraal sonder 'n ligbron kan wees nie, so is die Vader en die Seun van ewigheid af nie sonder mekaar nie. Maar toe kom die dwaalleraars en sê: 'Goed, maar die Ligstraal (die Seun) is darem altyd ondergeskik aan die Ligbron (die Vader).' Om hierdie dwaalleer by die wortel af te sny, het die Kerk toe op grond van die Bybel (Joh 17: 3; Op 3: 7 en 19: 11) gesê: 'waaragtige God uit waaragtige God.'

So kan ' $n$ mens voortgaan: Wanneer Antwoord 68 van die Heidelbergse Kategismus stel dat daar net twee sakramente, die Doop en Nagmaal is, dan word dit uit die Bybel afgrensend teenoor die leer van die sewe sakramente by Rome gestel en wanneer byvoorbeeld die Nederlandse Geloofsbelydenis in artikel 34 sê dat iemand 'slegs een maal gedoop moet word met die enige doop, sonder om dit ooit te herhaal', dan bely dit hierdie waarheid op grond van die Bybel teenoor die Wederdopers se dwaalleer van die herdoop.

\section{DIE NOODSAAK VAN 'N NUWE GELOOFSBELYDENIS}

Tot dusver het ons gehandel oor die wenslikheid en uitvoerbaarheid van ' $n$ nuwe ekumeniese geloofsbelydenis vir vandag. Ons het eerstens die redes nagegaan wat agter die pleidooie lê van 'n paar resente voorbeelde wat om 'n nuwe (ekumeniese) geloofsbelydenis vra. Tweedens het ons aangedui watter faktore die Kerk as 't ware dwing om 'n geloofsbelydenis op te stel. Ons het hoofsaaklik drie beweegredes gevind, naamlik:

- dat die geloofsbelydenis as 'n vaandel sal dien om 'n bepaalde Kerk te identifiseer, af te sonder, onderling te verbind en te inspireer;

- dat die kerk met die oog op die kategese en sending 'n kort 
oorsigtelike en sistematiese samevatting van die Bybelse hoofpunte van sy geloof sal hê en derdens;

- dat die geloofsbelydenis 'n noukeurig-geformuleerde polemiese afgrensing teen dwaalleringe is.

Die vraag wat ons wil beantwoord, is of daar in die lig van bogenoemde redes, genoegsame gronde vir ons Kerk en vir die Christelike kerk in die algemeen is, om vandag, vir vandag, 'n nuwe geloofsbelydenis (desnoods 'n ekumeniese geloofsbelydenis) op te stel? Op hierdie vraag wil ons in die vorm van die volgende punte antwoord:

\subsection{Eietydse leef- en dinkwêreld}

Dit is duidelik dat die leef- en dinkwêreld en ook die taal van die moderne mens aansienlik verskil van die leefwêreld, dinkwêreld, taal en styl van dié mense wat in die eerste eeue van die Christelike kerk die drie ekumeniese belydenisse opgestel het èn van hulle wat vier honderd jaar gelede ons Kerk se drie Calvinistiese geloofsbelydenisse op skrif gestel het. Hieruit volg dat die Kerk die taak nie kan ontwyk om die oer-oue belydenisse gedurigdeur in die taal van vandag te vertaal nie.

Wat in ons verband van beslissende belang is, is hoe hierdie vertaling gaan gebeur?

Die eerste en miskien die maklikste taak, is om die woorde en sinne van die ou belydenisse in verstaanbare byderwetse Afrikaans weer te gee. Aan hierdie taak gee ons Kerk dan ook gedurigdeur aandag. So het die eerste Afrikaanse vertaling van ons belydenisse in 1945 verskyn en die tweede, grondig hersiene vertaling sal nog gedurende die negentien-tagtigs verskyn. Onlangs is daar van die Heidelbergse Kategismus ' $n$ uitgawe 'in vier teksuitgawes met inleiding en teksvergelyking deur JP Oberholzer' gepubliseer (Oberholzer 1986).

'n Tweede 'vertalingstaak' is die uitleg van die belydenisse se inhoud vir die mense van vandag. Dit is veral die taak van dié teologiese wetenskap wat ons die Dogmatiek noem. Vir hierdie vertalingswerk, naamlik die uitleg, is drie 'stappe' nodig om dit verantwoordelik en noukeurig te doen. Eerstens sal moet bepaal word wat die oorspronklike betekenis van hierdie belydenisuitsprake daar-en-toe was. Om dit te bepaal, is noukeurige studie van beide die taalkundige èn historiese konteks van die belydenisuitsprake nodig. ' $n$ Mens moet onthou dat daar dikwels eeue se stryd was om die Bybelse waarheid teenoor die 
dwaalleer bevredigend te formuleer. Die tweede stap sal wees om hierdie oorspronklike betekenis van die betrokke belydenisuitsprake te toets aan die resultate van die moderne wetenskaplike Skrifuitleg. Vir hierdie doel het die 1979-Algemene Kerkvergadering dan ook 'n kommissie benoem om na te gaan of al die Skrifbewyse wat die vadere vir die substansiëring van die Heidelbergse Kategismus se Vrae en Antwoorde aangevoer het, nog in die lig van vandag se Skrifuitleg steekhoudend is. Dis nie dat die Kerk met die Heidelbergse Kategismus se leerinhoud fout gevind het nie, maar dit is alleen dat ons Kerk besef dat om werklik hervormd te wees, die Kerk gedurigdeur nie net sy lewe nie, maar ook sy leer aan die Skrif sal moet toets. Die derde stap in die uitleg van die ou belydenisse sal wees om dié waarheid wat gevind is deur dit aan die Skrif te toets, weer te gee in woorde, begrippe, sinsnedes en verbande wat vir die moderne mens in sy besondere leefen dinkwêreld verstaanbaar is.

Kortom beteken hierdie hele proses dat die teologie deur vertaling en uitleg van die ou belydenisse, die Kerk nie soseer tot die vorming van die nuwe belydenis lei nie, maar veeleer dat dit daartoe dien dat ou belydenisse duidelik word en opnuut en daadwerklik deur die kerk bely sal word.

\subsection{Die moderne mens is anti-metafisies en anti-mitologies}

Maar die genoemde derde stap in die uitleg van die ou belydenisse (naamlik om dié waarhede wat gevind en aan die Skrif getoets is, aan die moderne mens met sy eietydse leef- en dinkwêreld oor te dra), is deur vrysinnige teoloë in die verlede (en word deur baie hedendaagse teoloë) só hanteer dat hulle stel dat die waarhede van die ou belydenisse wat gevind en aan die Skrif getoets is, nie net wat vorm betref by die moderne mens aangepas moet word nie, maar dat hulle ook wat die inhoud aangaan, aangepas moet word by wat vir die moderne mens aanvaarbaar is. Vanuit hierdie gesigspunt word dan byvoorbeeld gestel dat die moderne mens, gevorm deur die tegniek en natuurwetenskap, nie meer dinge aanvaar wat nie algemeen ervaarbaar, kwantitatief meetbaar en weegbaar is nie. Die moderne mens (só beweer hierdie teoloë), is beslis anti-metafisies en anti-mitologies ingestel. Daarom beskou hulle God nie soseer as die transendente Skepper nie, maar wil hulle veeleer klem lê op die mens Jesus van Nasaret. Trouens, wie Hom gesien het, het die Vader gesien (Joh 14: 9). Op gelyke wyse (só stel hierdie teoloë) aanvaar die moderne mens nie sulke mitiese dinge soos 
die maagdelike geboorte van Jesus, sy wonderwerke, sy opstanding, hemelvaart, wederkoms en die hiernamaals nie; ook nie sulke metafisiese spekulasies soos die leer van die Drie-eenheid, die onderhouding, die ewige verkiesing en so meer nie. Wat die moderne mens wel verstaan (én wat hom ook aanspreek en aktief laat deelneem), is dat Jesus van Nasaret die boodskap van naasteliefde, bevryding, vryheid en versoening tussen mense gebring het. Hy het dit nie net verkondig nie, maar as voorbeeld (wat ons ook moet navolg) vir ons uitgeleef en sy lewe daarvoor gegee (vgl hieroor Sperna Weiland 1966 en 1971; Engelbrecht 1964; 1967 en 1969).

\subsection{Die sosiaal-politieke gerigtheid van die moderne mens}

Wat beteken hierdie teologie wat stel dat die boodskap van die Bybel nie soseer op die ewige hiernamaals gerig is nie (maar veeleer op die sosiaal-politieke werklikheid), vir die opstel van 'n nuwe belydenis? Die antwoord is: Die ou belydenisse is duidelik ná Bo èn op die ewige toekoms gerig en hulle vertolk nie soseer hierdie nuwe boodskap van sosiaal-politieke bevryding, vryheid en die aardse ryk van geregtigheid nie. Daarom dring hierdie teoloë en hulle kerke daarop aan dat daar'n nuwe belydenis opgestel moet word wat hierdie nuwe verstaan van die Bybelse boodskap belydend onder woorde moet bring. Omdat hierdie sosiaal-politieke boodskap deur ' $n$ groot deel van die Wêreldraad van Kerke aanvaar word, is hulle daarvan oortuig dat so 'n geloofsbelydenis, net ' $n$ ekumeniese geloofsbelydenis kan wees!

\subsection{Ekumeniese eenheid}

Dit is natuurlik nie alle teoloë wat hierdie sosiaal-politieke geloofsbelydenis as die enigste moontlikheid vir 'n nuwe ekumeniese geloofsbelydenis sien nie. Daar is wel sommige (maar hulle is ' $n$ baie klein minderheid), by wie daar die egte verlange leef dat die Kerk van Christus weer één sal word omdat dit die één waarheid van die Bybel eenstemmig bely. Hierdie egte ekumeniese belydenis lyk egter vir my heeltemal onmoontlik. Dit is bekend hoe die Wêreldraad van Kerke in die begin geworstel het oor 'n basis-formule vir die kerke wat wil aansluit. 'n Mens sou verwag dat hulle die drie Ekumeniese Belydenisse kon kies. Maar helaas! Uiteindelik is prakties slegs op die skraal formule 'Jesus Christus is Here' ooreengekom, maar dan met die uitdruklike verstandhouding dat dit nie teologies verder uitgelê moes 
word nie, want dan sal sekere leerverskille na vore tree wat die kerke uitmekaar sal laat spat! As dit die geval was tussen oorwegend Protestants ? kerke, wat sal gebeur as die hele groot Rooms-Katolieke Kerk (wat baie prys op die leer stel), nog bykom!

Dit lyk of die spreuk van die Moral Rearmament met sy sterk sosiale gerigtheid (kyk Boerwinkel 1959: 42-45), naamlik 'fruits unite, but roots divide' ook van toepassing is op die saak van 'n moontlike ekumeniese belydenis. As dit by die 'roots' kom, die eintlike dinge uit die Bybel wat werklik saak maak, dan sal hulle uiteenspat; maar wanneer dit by die 'fruits' kom, in hulle geval die sosiaal-politieke program, dan vind hulle mekaar. Die vraag is net: Is die opstelling van so 'n program nog 'n egte gelóófsbelydenis?

\section{EIE SITUASIE}

Wat ons Kerk en 'n moontlike nuwe of aanvullende geloofsbelydenis betref, wil ons kortliks die volgende stel:

Indien dit na wetenskaplik-verantwoorde Skrifstudie blyk dat sekere aksente anders gelê moet word en sekere dinge anders gesê moet word, dan sal ons Kerk die taak van 'n nuwe belydenis in verantwoordelikheid aan die Skrif moet aanpak, sonder om die historiese erfgoed sonder meer te verwaarloos of af te skryf. Ons dink byvoorbeeld aan die poging van The Reformed Church in America wat, soos ons vroeër reeds beskryf het, groot dele van die bestaande belydenisse na noukeurige Skrifstudie gehandhaaf het en tog byvoorbeeld die vraag gevra het: 'Moet ons, as ons aan die soewereine God al die eer wil gee vir ons verlossing in en deur Jesus Christus, aanhou praat in terme van die ewige raadsbesluite, verborge wil en ewige verkiesing?' Ons moet toegee dat hierdie spreekwyse baie vrae by ons lidmate laat ontstaan en dat die riglyne van die Nederlandse Hervormde Kerk in 1960 oor die verkiesing en die bydrae van Karl Barth in dié verband, nuwe perspektiewe open (Barth 1941 en Synode NHK 1961). Dit is ' $n$ ander vraag of dit in die vorm van ' $n$ nuwe belydenis moet gebeur en of dit by wyse van toeligting by Artikel XVI van die Nederlandse Geloofsbelydenis en by die Dordtse Leerreëls gevoeg moet word?

Dit is bekend dat ons Kerk gedurigdeur besig is om ander, meer eietydse vorme te soek en op te stel vir haar kategetiese onderrig omdat aangevoel word dat die Heidelbergse Kategismus, die Kortbegrip en die huidige Geloofsleer miskien nie byderwets genoeg is nie. Ek glo dat dit grootliks die vorm (soos formulerings en rangskikkings van die stof 
van genoemde 'kategismusse') raak, maar ek glo óók dat dit wel op die inhoud betrekking het. Daar word naamlik gevoel dat baie dinge wat in die sestiende eeu (met die kerkhervorming) brandende vrae was en in die Kategismus opgeneem is, nie meer vandag so relevant is nie. Aan die ander kant sit ons vandag gekonfronteer met magtige ideologieë (soos die Kommunisme), met nuwe sektes en godsdienstige strominge, terwyl alle vreemde godsdienste deur die verbeterde kommunikasiemiddele (byvoorbeeld die televisie) naby aan ons gekom het. Die sestiende eeu was met ander werklikhede, strominge en probleme gekonfronteer as ons. Die vraag is of ons Kerk nie vandag teenoor dié probleme waarmee ons op godsdienstige gebied gekonfronteer word, belydend vanuit die Bybel die waarheid van God moet laat klink nie? Is die blote toeligting van die oue en aanvullende uiteensettings genoeg, òf moet daar tot offisiële belydenisuitsprake gekom word? 'n Ander vraag is: Was die Kortbegrip en is die Geloofsleer en is ons nuwe kategesehandboeke, nie prakties (de facto, maar nie de iure nie) tòg maar geloofsbelydenisse van ons Kerk nie? Is daarin nie uiteengesit wat ons Kerk vandag op grond van die Bybel glo en leer nie?

Ten slotte: Karl Barth het eenmaal gesê dat as 'n mens wil uitvind wat 'n kerk op 'n bepaalde tydstip glo, moet jy veral na sy Psalm- en Gesangboek gaan kyk, veral ook na wat 'n kerk op 'n bepaalde tydstip werklik sing. In dié lig kan ons vra: Lê daar nie feitelik in ons nuwe Gesangboek 'n nuwe geloofsbelydenis opgesluit, of ten minste elemente en perspektiewe van 'n nuwe geloofsbelydenis nie?

Die vraag aan ons Kerk is dus of daar nie in plaas van aanvullende toeligting by en van die oue, eerder nuwe belydende spreke moet wees nie?

\section{Literatuurverwysings}

BAKHUIZEN VAN DEN BRINK, JN 1940. De Nederlandsche Belijdenisgeschriften. Amsterdam: Uitg Holland.

BARTH, K 1941. Kirchliche Dogmatik II/2. Zürich: EV Zollikon.

BOERWINKEL, F 1959. Kerk en secte. 's-Gravenhage: Boekencentrum.

CULLMANN, O 1959. Rooms-Katolieken en Protestanten. Nijkerk: Callenbach.

ENGELBRECHT, BJ 1964. Die Kommunistiese aanslag op die kerk, in Christendom teen Kommunisme. Pretoria: Volkskongres.

ENGELBRECHT, BJ [1967]. Hedendaagse krisispunte in die teologie. HTS 23/1, 5-23.

ENGELBRECHT, BJ [1969]. Die antwoord en taak van die kerk ten opsigte van sekularisasie. HTS 24/3, 142-154.

ENGELBRECHT, BJ 1974. Die teologie van die hoop en die teologie van die revolusie, in Die Bybel en die moderne mens, 39-51. Pretoria: SA Akademie.

HEIDEMAN, EP 1975. Our song of hope. Grand Rapids, Michigan: Eerdmans. 
KOOPMANS, J 1949. De Nederlandse Geloofsbelijdenis. 3de Druk. Amsterdam: Uitg Holland.

NIESEL, W 1938. Bekenntnisschriften und Kirchenordnungen der nach Gottes Wort reformierten Kirche. 2 Aufl. Zürich: EV Z.

OBERHOLZER, JP 1986. Die Heidelbergse Kategismus in vier teksuitgawes, met inleiding en teksvergelyking. Pretoria: Kital.

SPERNA WEILAND, J 1966. Oriëntatie. Baarn: Wereldvenster.

SPERNA WEILAND, J 1971. Voortgezette oriëntatie. Baarn: Wereldvenster.

SYNODE DER NEDERLANDSE HERVORMDE KERK 1961. De uitverkiezing. s'Gravenhage: Boekencentrum. 